Journal of Social Research in Uzbekistan

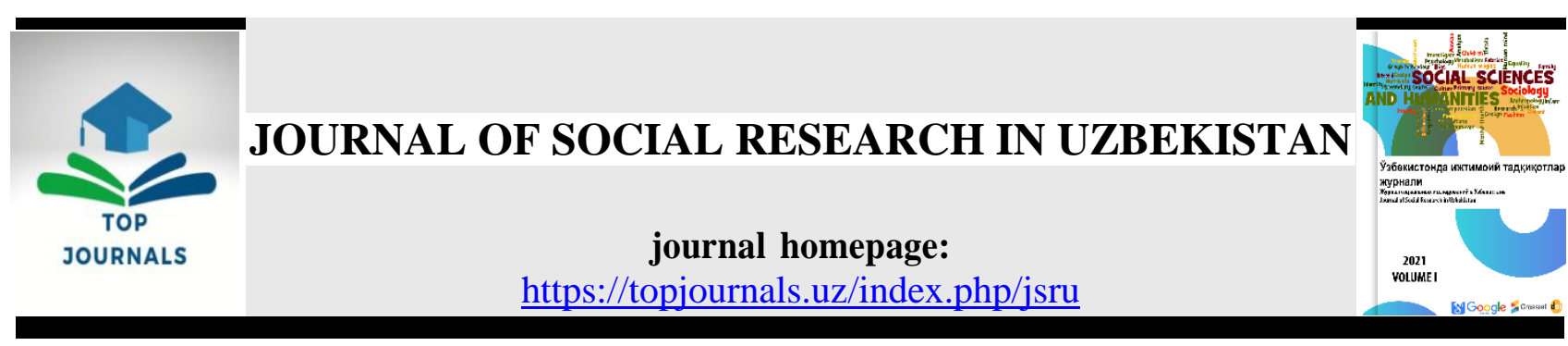

\title{
TRADITIONAL CARPETS OF THE LIVESTOCK POPULATION OF THE NURATA OASIS IN LATE XIX - BEGINNING OF XX CENTURY
}

(Based on the analysis of historical and ethnographic materials)

\author{
Khayriddin A. Berdiev \\ Senior Lecturer, PhD. \\ Tashkent State Technical University \\ Uzbekistan \\ bxa_68@mail.ru
}

Ravshan S. Tashmurodov

Senior Lecturer

Tashkent State Technical University

Uzbekistan

t.ravshan@gmail.com

\section{ABOUT ARTICLE}

Key words: Nurata oasis, crafts, Abstract: The article is devoted to the traditional, ethnos, ethno-local, carpet specific types of traditional carpet weaving in the weaving, cattle breeding, people, lifestyle, Nurata oasis and the research conducted by textiles, scientists, specialist, heritage, scientists to study them. The features of the attitude. traditions of carpet weaving, transmitted from ancestors to generations, the state of the carpet

Received: 04.01.22

Accepted: 10.01.22

Published: 29.01.22 weaving traditions of the Nurata oasis, as well as historical and ethnographic features are studied. Attention is paid to the traditions of carpet weaving, which occupies a worthy place in the lifestyle of the oasis population, and the historical and ethnographic description of some types of carpets that have survived in the oasis to this day. Described attention to the production of types of carpets and proposals in this regard. In general, some aspects of the art of carpet weaving, which played a key role in the traditional crafts of the Turkmen, tom, palace and Uzbeks, Kazakhs, Tajiks, who have been living in the Nurata oasis for many years, are highlighted. After all, carpet weaving, which is the oldest traditional textile industry of mankind, has always had its own ethno-local features. A special place in this is occupied by the Nurata oasis, one of the historical and cultural regions of Uzbekistan. 


\section{ХІХ АСР ОХИРИ - ХХ АСР БОШЛАРИДА НУРОТА ВОХАСИ ЧОРВАДОР АХОЛИСИНИНГ АЪАНАВИЙ ГИЛАМДЎЗЛИГИ}

(Тарихий -этнографик материаллар тахлили асосида)

\section{Хайриддин А. Бердиев}

Kатта уц̧итувчи, PhD.

Тошкент давлат техника университети

Ўзбекистон

bxa_68@mail.ru

\section{Равщан С. Ташмуродов}

Катта ўқитувчи

Тошкент давлат техника университети

Ўзекистон

t.ravshan@gmail.com

\section{МАКОЛА ХАКИДА}

Калит сўзлар: Нурота вохаси, Аннотация: Мақола хунарманд-
хунармандчилик, анъанавий, этнос, чиликнинг анъанавий гиламдўзлик этнолокал, гиламдўзлик, чорвадор ахоли, турининг Нурота вохасига хос турлари ва халқ, турмуш тарзи, тўқимачилик, уларни ўрганиш бўйича олимларнинг олиб олимлар, мутахассис, мерос, муносабат. борган тадқиқотларига бағишланган. Унда гиламдўзлик анъаналарининг ажодлардан авлодларга ўтиб келаётган хусусиятлари, Нурота вохаси гиламдўзлик анъана-ларининг холати хамда тарихийэтнографик хусусиятлари ўрганилган. Воха ахолиси турмуш тарзида муносиб ўрин тутган гиламдўзлик анъаналарига эътибор қаратилиб, вохада хозирги кунга қадар сақланиб қолган айрим гилам турларига тарихий-этнографик жихатдан таъриф берилган. Гиламчилик турлари ишлаб чиқарилишига бўлган эътибор ва бу борада таклифлар баён қилинган. Умуман, унда Нурота вохасида узоқ йиллар мобайнида истиқомат қилган воханинг туркман, тома, сарой хамда ўзбек, қозоқ, тожиклар томонидан анъанавий хунармандчиликда асосий ўрин тутган гиламдўзлик санъатининг айрим жихатларини ёритилган. Зеро, инсониятнинг қадимги анъанавий тўқимачилик сохаси бўлган гиламдўзлик барча даврларда ўзига хос этнолокал хусусиятларга эга бўлиб келган. Бунда Ўзбекистоннинг тарихий-маданий минтақаларидан бири Нурота вохаси алохида ўрин эгаллайди. 


\section{Кириш /Введение /Intpoduction:}

Азалдан Марказий Осиё халқлари турмуш тарзида хунармандчилик сохасининг кўплаб турлари шаклланган ва улар махаллий халқлар турмуш тарзида алохида ўринга эга бўлган. Булар қаторида дурадгорлик, темирчилик, ёғочсозлик, кулолчилик, каштачилик, тақинчоқлар ясаш каби хунармандчилик турлари мухим ўрин тутган. Тўқимачилик йўналишида эса гилам тўқиш ва каштачиликнинг махаллий халқларга хос намуналари яратилиб, уларда ўша халқларнинг турмуш тарзи, дунёқараши хамда миллий тафаккури акс этган. Улар узоқ йиллар мобайнида асрлардан асрларга ўтиб, ранг баранг шаклда, турли ўлчамларда аждодлардан авлодларга етказилган. Айниқса, хўжалик хаётида чорвачилик асосий ўрин тутувчи халқлар хаётида гиламдўзлик анчагина тараққий этиб, унда ўзига хос мактаблар шаклланган. Бу эса анаъанавий хунармандчиликнинг гиламдўзлик санъати ўзининг узоқ тарихий-этнографик хусусиятларига эга эканлигини тасдиқлайди.

Ана шундай тарихий-маданий минтақалардан бири Нурота вохаси бўлиб, тадқиқотларга кўра Нурота тоғ тизмаси ён бағрларида яшаган ўзбек ва тожик этносларининг гилам тўқиш анъаналари алохида ажралиб турганлигини ва миллий композицияни ташкил этган. Агарда уларнинг ўрганилиш тарихига эътибор қаратилса, XX acp 40-йиллари ўрталаригача улар яхши ўрганилмаганлигини ва Ўрта Осиё гиламлари хусусида рус ва хорижий адабиётларда бу хақда маълумотлар кам учрашини тасдиқлади. Анъанавий хунармандчиликдаги тўқимачилик сохаси гарчи собиқ Иттифоқ даврида “эскилик сарқити”, деб қаралган бўлса-да, бугунги кунга келиб илмий асосга эга бўлган долзарб муаммога айланди хамда ушбу сохани янада чуқурроқ ўрганиш долзарб ахамият касб этмокда.

Бу борада айниқса Ўзбекистон Республикаси Президенти Ш.Мирзиёев томонидан имзоланган 2017 йил 17 ноябрдаги «Хунармандчиликни янада ривожлантириш ва хунармандларни хар томонлама қўллаб-қувватлаш чора-тадбирлари тўғрисида» ПФ-5242-сон Фармони[1. https://president.uz/uz/] халқ бадиий хунармандчилиги ва амалий санъатини янада ривожлантиришни назарда тутувчи мухим норматив-хуқуқий хужжат сифатида алохида ахамиятга эга бўлди. Зеро, хунармандчиликнинг барча турларини асраб авайлаш, ишлаб чиқариш анъаналарини мукаммал ўрганиш, моддий ва ашёвий манбаларга асосланиб халқ амалий санъати намуналарини тиклаш ва келажак авлодларга етказиш мухим ўринга эга.

Асосий қисм /Основная часть /Main part: Республикамизнинг тарихий-этнографик минтақаларидан бири бўлган Нурота вохаси азалдан турли этносларнинг ўзаро этномаданий алоқалари, ассимиляциялашуви учун ўзига хос этномулоқот худуди бўлганлиги, бундай ўзаро муносабатлар худуд ахолисининг анъанавий машғулотларида, хусусан чорвадор ахоли моддий маданияти айниқса, аёлларнинг гилам тўқиш анъаналарида яхши сақланганлигини 
кўришимиз мумкин. Нурота вохасида азалдан яратилган хунармандчилик махсулотлари, айниқса гиламлар ўзининг бетакрор шакллари ва безаклари билан бошқа худудлардан ажралиб турган.

Муаммонинг ўрганилишига эътибор қаратилса, тадқиқотларга кўра, XIX аср охир XX асрда Нурота вохаси анъанавий хунармандчилиги тарихини ўрганишга бағишланган барча материалларни уч гурухга ажратиш мумкин:

1) Россия империяси даврида чоп этилган адабиётлар;

2) Совет даврида яратилган адабиётлар;

3) Ўзбекистон мустақиллиги йилларида олиб борилган тадқиқотлар.

Россия империяси Ўрта Осиёни босиб олгандан кейин мустамлака худудини мукаммал ўрганиш мақсадида бир қатор илмий экпедициялар уюштирилганлиги тарихдан аён. Улар орасида олимлар хам бўлиб, улар қаторида Д.Н.Логофет, Н.В.Хаников, Н.А. Маев, А.Д.Гребенкинлар Ўрта Осиё, хусусан, Бухоро амирлиги шахарлари, бозорлари, ахолисининг этник таркиби, кийим-кечаклари, машғулотлари тўғрисида мухим маълумотларни келтириб ўтганлар. [2, - 245]. Бундан ташқари А.Бёрнс, А.П.Федченко, П.И. Небольсин, П.И. Пашино, А.Вамбери, Н.Ф. Петровский, М. Бекчурин, Е.К. Мейндорф, А.Кун, Л.Ф.Костенко, К.К.Пален, В.И.Масальский ва бошқалар томонидан чоп эттирилган асарларда хам хунармадчиликнинг айрим сохалари ўрин олган. Улар орасида А. Семёновнинг «Бухоро манғитлари тарихи» номли мақоласида ушбу амирликнинг хўжалик хаётида мухим ўрин тутган бир қанча хунармадчиликнинг гиламчилик турига тегишли маълумотлар учрайди[3,- С. 58.].

Советлар давридаги тадқиқотларда гилам тўқиш билан боғлиқ машғулот турларига алохида олинган минтақалар доирасида эътибор қаратилмаган бўлсада, қатор олимлар, жумладан И.Краузе, Н.Е.Симаков, В.К.Розводский, А.А. Фелькерзам, М.С.Андреев, М.Ф. Гаврилов, А.А.Семёнов, В.Г.Мошкова каби тадқиқотчилар томонидан ёзилган маълумотларда Марказий Осиё халқларининг мухим машғулотларидан бири бўлган тўқимачилик ва унга ёндош касб турлари, ишлаб чиқариш жараёнларида иштирок этган хунармандчилик уюшмалари тўғрисидаги айрим фикр-мулохазалар жамланган. Уларда қисман бўлсада, Нурота гиламдўзлигига оид айрим маълумотлар хам учрайди.

Агарда мазкур худуднинг тарихий-этноргафик манзарасига эътибор қаратилса, минтақа азалдан махаллий ва хорижий тадқиқотчиларни ўзига жалб этиб келганлигини кўришимиз мумкин. Бу борада бир қанча махаллий олимлар ва мутахассислар вохада қатор изланишлар олиб борган бўлиб, улар айниқса мустақиллик йилларида янада кенгайганлигини пайқашимиз мумкин. Масалан воха ахолисининг этник таркиби, жамоавий турмуш тарзи, хўжалик хаёти, аёллар тақинчоқлари, ахоли манзилгохларининг топонимик ва 
этнотопонимик хусусиятлари каби масалалар Х.Бердиев, Ф.Толипов, Г.Юлдашева, Ў.Орипов, Т.Салимов, А.П.Шевяков, А.Тоғаев, каби олимлар томонидан ўрганилган. Тадқиқотлардан кўзланган мақсад Нурота вохаси ахолиси тарихи, этнографик хусусиятлари у ёки бу тарза тадқиқ этилган бўлсада, вохада анъанавий хунармандчиликнинг гиламдўзлик анъаналари алохида илмий тадқиқот объекти сифатида тарихий-этнографик жихатдан хали ўрганилмаганлигини тасдиқлади.

Аммо ўрганилаётган масаланинг тарихшунсолигига эътибор қаратилса, мустақиллик йилларида амалга оширилган илмий ишлар қаторида бевосита Нурота вохасига тааллуқли воха аёлларининг анъанавий кийим- кечаклари ва тақинчоқлари масаласи этнолог олима Г.К.Юлдашева томонидан алохида диссертация тадқиқоти сифатида ўрганилган бўлсада, гиламдўзлик анъаналарига қисман эътибор қаратиб ўтилганлигини кўришимиз мумкин. Унда муаллиф аёлларнинг анъанавий кийим-кечаклари ва тақинчоқларини дала этнографик маълумотлари асосида тадқиқ этади[4, - 21 с.]. Муаллиф ўз ишида воха ахолисининг этник таркиби, хўжалик турмуш тарзи каби масалаларга хам баъзи ўринларда тўхталиб ўтган.

Этнолог олим Ф. Толипов хам Нурота вохаси жамоа анъаналари ва минтақа ахолиси турмуш тарзи хақида тадқиқотлар олиб борара экан, хунармандчиликнинг вохага хос турлари, айниқса гилма тўқиш, каштачилик анъаналари, XX аср бошларига келиб капиталистик муносабатлар, сиёсий, иқтисодий, ижтимоий жараёнларнинг мазкур сохаларга таъсири, қишлоқ аёлларининг кохоз ишларига жалб этилиши натижасида уй хунармандчилигининг айрим турларининг қисқариши хусусида маълумотлар бериб ўтган. Энг асосийси мазкур машғулот турларининг этник ва локал жихатлари ва айрим тарнсформацион жараёнлар дала маълумотлари ва илмий адабиётлар тахлили орқали воханинг Гараша қишлоғи мисолида ёритишга харакат қилинган [6. 2008] Т.ф.н Х. Бердиев эса вохада жойлашган ахоли манзилгохлари, хусусан жой номлари, яъни тарихий топонимиясининг тахлилини тарихий нуқтаи назардан ўрганганлиги эътиборга моликдир [7.2019].

Дархақиқат, гиламдўзлик сохаси ахолининг азалдан турмуш тарзида тўшама махсулот тури сифатида дастлаб, ибтидоий жамоа даврида тери, хайвон жунлари, ўсимлик (қамиш ёки буйра) шаклида инсонларнинг дам олиши, хордиқ чиқариши учун мўлжалланган буюм шаклида пайдо бўлган. Бундай тўқимачилик буюмлари дастлаб хар бир натурал хўжалик эхтиёжларни қондиришга хизмат қилган. Янада тўғрироқ қилиб айтганда, гиламдўзлик тор хўжалик доирасида чуқур илдиз отган илк хунармандчилик шаклидир. Бугунги кунгача гиламдўзик ва тўқимачилик буюм хамда безак турларини ўрганган тадқиқотчилар маълумотларига кўра, у Кавказ, Олд Осиё (Эрон,Туркия, Миср) ва Марказий Осиёнинг кўчманчи ва ярим кўчманчи ахолиси турмуш тарзи билан узвий алоқадорлик махсули 
сифатида шаклланган. Бу борада П.Ф.Приображенский таъкидлаб ўтганидек, “Асосий вазифа тарихий манбалар асосида йирик маданий мажмуаларни қиёсий ўрганиш, уларнинг ўзаро боғлиқлик жихатларини аниқлашга қаратилиши керак” Асрлар ўтиши билан давлатчилик куртаклари ёйила бориши, ижтимоий-иқтисодий хўжалик турлари хаётда тўшама буюм жихози ва анча маданийлашган гиламчилик махсулотларига эхтиёжнинг нисбатан ортиши ушбу тармоқнинг янада ривожланишига сабаб бўлган. Яъни, чорвадор ахоли учун асосий хом ашё бўлган жунни йигириш ва қайта ишлаш орқали - бу махсулот хақиқий гиламдўзлик касбига айланди”[8.- Б. 29-30.].

Агарда ўтмишга назар ташланса, мамлакатимизнинг қадимги тарихий-этнографик минтақалари саналган Зарафшон, Сурхон вохалари, Фарғона водийси, Хоразм ва Тошкент вохаларидаги қадимги шахарларда ўзига хос хунармандчилик мактаблари бўлганлиги маълум. Нурота вохаси чорвадор ахолиси хаётида гилам тўқиш анъаналарининг мавжудлигини тасдиқловчи манбаларда, воханинг асосий ахолиси XIX аср охири-XX аср бошларига оид манбаларда “Нурота туркманлари” номи билан тилга олинади. 1928-1929 йилларда Г.Мошкова хукумат топшириғи билан палос ишлаб чиқариш артелларини таъсис этилиши бўйича экспедиция ходими сифатида гилам тўқиш билан шуғулланувчи туркман уруғлари яшаётган худудларда тадқиқотлар олиб борган [9.- С. 135-158, 238]. Муаллиф ташриф буюрган худудлардан бири Нурота вохаси бўлиб, унинг уқдиришича, вохада ўша пайтларда бошқа ўзбек қавмлари - бурқут, найман, турк, митан, қорақалпоқ ва қозоқлар сон жихатдан туркманлардан камроқ бўлган. Минтақада бир неча қишлоқларни ташкил қилган қозоқ уруғлари билан бир қаторда узоқ йиллардан буён ушбу ерларда яшаган бошқа ўзбек гурухлари хам мавжуд бўлган. Улардан бири томалар бўлиб, (улар Зулмкориз, Кўнасарой қишлоқларида яшаган) гилам тўқиш ва уни бозорларга олиб чиқиб сотиш ва айрибошлашда ном қозонганлар. Улар орасида бўхча, гажама, палос, кигиз, хўржинлар тўқиш алохида ўрин тутган. (1-расм) 


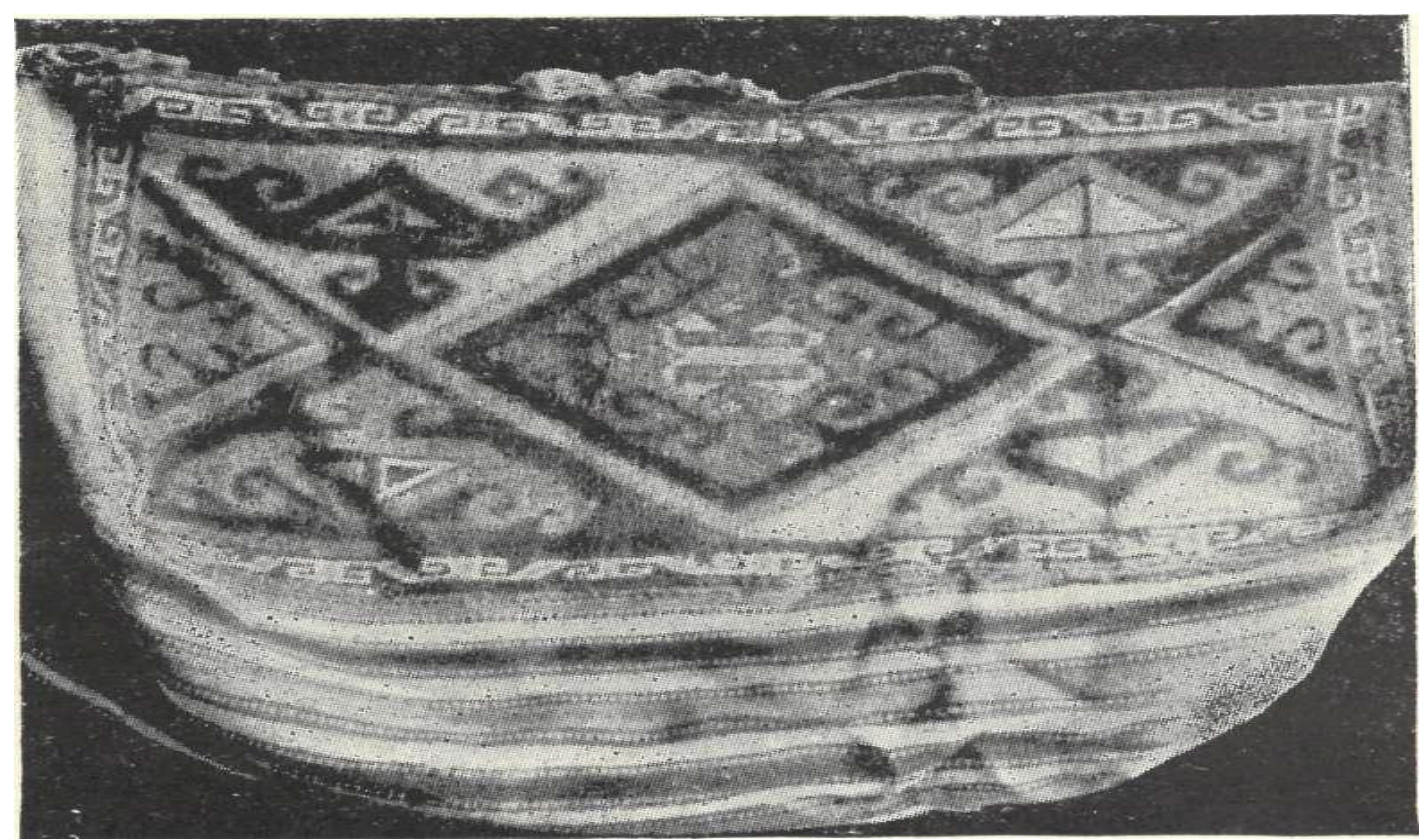

1-расм. Ўзбек тома уруғи гиламдўзлари томонидан тайёрланган хўржун

Бу борада тадқиқотчи В.Г.Мошкова ўз асарларида А.Д. Гребенкин, И.И.Зарубин, М.С. Андреевларнинг маълумотларига таяниб, XIX аср туркманларнинг қозоёқли, бўгажалли, қонжиғали, ойтамғали уруғлари ўзларини туркманларнинг “така” уруғига мансуб бўлганлиги туркман уруғларининг миллий ўзига хослиги, айниқса гиламчилик, каштачилик санъати асори атиқаларига катта қизиқиш билан муносабатда бўлганлигини ёзади. Муаллифнинг фикрича, ушбу уруғларнинг моддий мадангиятида ва кундалик хаётида айниқса Нурота гиламлари мухим ўрин тутади, деб ёзади. [10, - С. 135-158, 238. Унинг уқдиришича, Нурота гиламлари вохада яшовчи “олти ота туркман” ва “беш ота манғишлов” туркманлардан ташқари найман, туёқли, тукман, юз, қирқ, сарой каби бир қанча уруғларига кирувчи ахоли хам тайёрланган.

Хатто Нурота гиламлари сифат жихатдан Андижон, Самарқанд, Қашқадарё вилоятлари ва Амударё қуйи оқими ўзбеклари томонидан ишлаб чиқарилган гиламлардан яхши ва анча безакдор бўлганлигини қайд этади. Жиззах ва Нурота вохаси гиламдўзлари томонидан жунли тўшалмалар узун бўйли “жульхирс” ёки “жувараки”, унча катта ўлчамга эга бўлмаган калта патли гиламлар, патсиз гиламлардан “кохма”, шолча ва олачалар тўқилган. Бундан ташқари бу ерда деворга ўрнатишга мўлжалланган безакли “қиз гилам”лари, чорвадорларнинг “бўхжома” лари, ўтовларнинг сирт қисмига осиб ёки илиб қўйиладиган “қур”, “басқур”, патли гилам, патсиз “терма гилам” ёки “кохма” ва шу каби турли буюмлар ишлатилган тўрва (кичик қопча) халталар - (“напрамач”, “хўржун”- йўл халта) лардан иборат бўлган. (2-расм) 


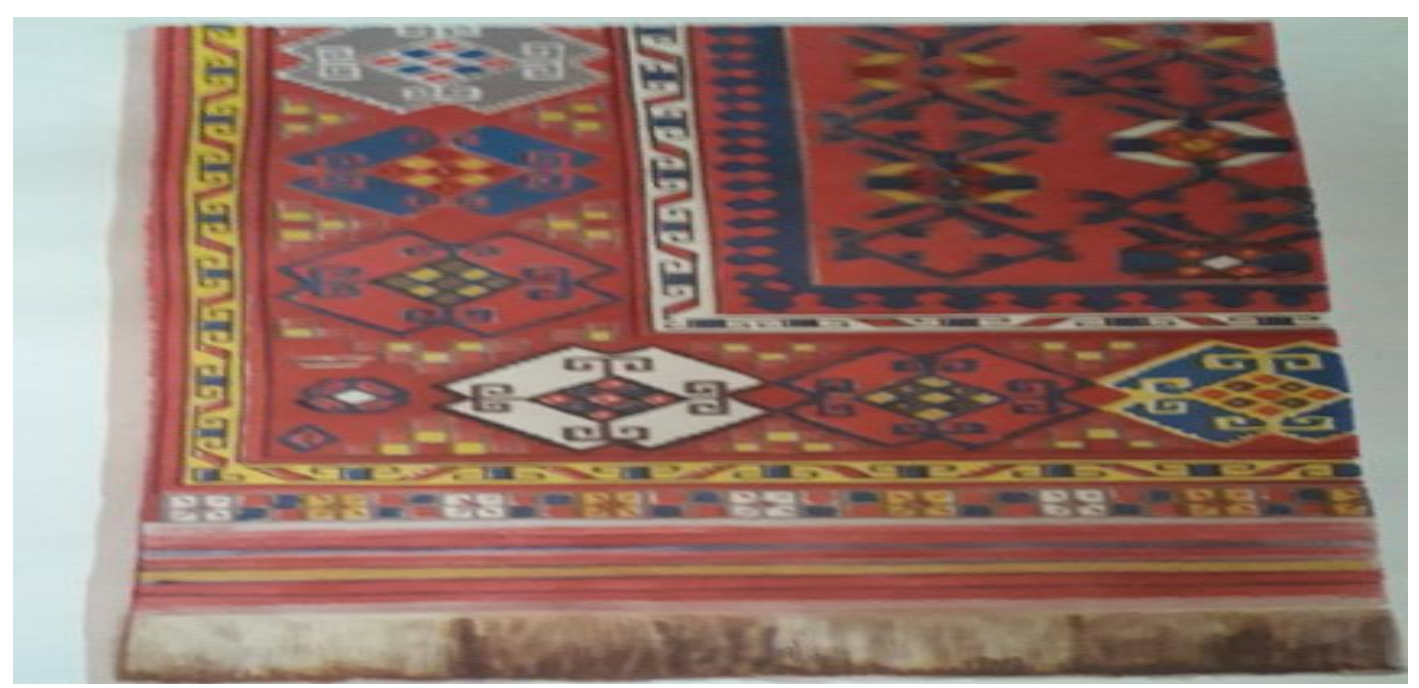

2-расм. Жўш қишлоғидаги патли гилам (фотосурат 2019 йил)

Аждодлардан авлодларга мерос тарзда ўтиб келган мазкур моддий маданият турининг ривожланиши XIX аср охирларида Нурота вохасининг ўзбек-туркман уруғига мансуб аёлларнинг гилам тўқиш машғулоти тажрибалари оша бошлаганлигини тасдиқлайди. Туб жой ахолининг айрим қатламлари учун гилам тўқиш қўшимча даромад манбаига айланган, яъни улар ўз гиламларини бозорларда сотганлар ва ўз оилаларини шу орқали боққанлар. Хатто, жундан тўқилган патли ва патсиз гиламлар Самарқанд ва Бухородаги бозорларга олиб борилган. Уларни асосан ўзбек ва тожиклар сотиб олишган. Нурота гиламларини Самарқанд ахолиси уйларида, чойхоналарда ишлатишиб, мазкур турдаги махсулотларни Митандан то Самарқандгача бўлган худудларда жойлашган кўплаб дехқон уйларида учратиш мумкин бўлган. Гилам сотувчиларнинг сўзларига кўра, кўплаб Нурота гиламлари XX аср бошларида, хусусан XX аср 20-30 йилларида хам Самарқанд гилам бозорларига олиб бориб сотилган. Махаллий савдо расталарида улар Нуротанинг "оқ тов" гиламлари номи билан машхур бўлган. Самарқанд вилояти бозорларида Нурота гиламлари нуфузи айниқса биринчи жахон урушигача бўлган даврларда бир мунча кўпайган.

Нуротанинг Қоратош (Оқтоғнинг Зарафшон вохасига туташ қисмида жойлашган) жанубий қисмидаги савдогарлар ва қозоқ бойлари гиламлар сотиб олиниб, чайқовчилар уларни қиммат бахода пуллаб, ўз даромадларини оширганлар[11, - С. 68.]. Аммо биринчи жахон уруши ва Россиядаги фуқаролар урушининг оғир йилларида ушбу худудда гилам махсулотлари ишлаб чиқариш сезиларли даражада пасайган. Жун ва бўёқларнинг етишмаслиги, махсулотларнинг эркин сотилиш имконияти йўқлиги ушбу худудда гилам ишлаб чиқаришни секинлашишига сабаб бўлган. Айниқса XX acp 30-40-йилларда қишлоқларда патли гилам тўкувчи аёллар сони камайиб борган, Бу борада В.Г.Мошкова 
Нурота туркманлари турмуш тарзи билан чуқурроқ танишиш учун кўплаб хонадонларда бўлганлигини ёзиб қолдирган. Бу ерда катта ёшдаги аёллар (камида 40 ёш) патли гилам тўқиш билан машғул бўлганликларини ўз асарларида қайд этганлиги эътиборга моликдир.

Хулоса /Выводы /Conclusion: Нурота вохси ахолисиининг гилам тўқиш анъаналари узоқ вақт давомида шаклланган этномаданият махсули бўлиб, бир вақтнинг ўзида ушбу худудда яшаган ахолининг ижодкорлигининг натижаси сифатида алохида ахамият касб этади. Шубхасиз, Нурота тоғ тизмаси атрофларида яшаган ахолининг гилам тўқиши урфодатларида нафақат воханингўзбек халқи, балки бошқа халқлар маданиятида хам ўз ифодасини топганлигини хам кўриш мумкин. Умуман, гиламдўзлик анъаналарининг ажодлардан авлодларга ўтиб келаётган хусусиятлари, бу борада Нурота туркманлари чорвадор ахолисининг гилам тўқиш анъаналари ва уларнинг умумий ва этнолокал хусусиятлари ўзига хос моддий маданият компоненти сифатида алохида ўринга эга эканлигини, уларни алохида олинган мавзу сифатида ўрганиш эса мухим ахамият касб этишини тасдқилади. Шу боисдан мазкур мақолада ёритилаётган масаланинг долзарбдлиги нуқтаи назаридан қуйидаги таклифларни бериб ўтиш мақсадаг мувофиқ:

Биринчидан, махаллий ахолининг гилам тўқиш анъаналарини сақлаш ва келажак авлодларга етказиш нуқтаи назаридан худудларда алохида гиламчилик мактаблари очиш ва уларга ёшларни тобора кўпроқ жалб этиш;

Иккинчидан, республикада ушбу сохани янада такомиллаштириш, Нурота тоғ тизмаси ахолиси анаъанавий моддий маданиятининг қатор тармоқларини гилам тўқиш анъаналари билан биргаликда мувофиқлаштириш, ушбу йўналишдаги илмий тадқиқотларни янада кенгайтириш;

Учинчидан, бугунги кунда махаллий саноатда замонавий типдаги гиламларга эхтиёж кундан-кунга ортиб бораётган бир шароитда қўлда тўқилган гилам ва палосларга эхтиёж эса йўқолиб бормоқда. Шу боис давлат ахамияти даражасида уларни сақлаб қолиш чораларини кўриш, бу борада зарур норматив-хуқуқий базани шакллантириш, ривожлантириш, зарур бўлса халқаро алоқалар кўламида миллий гиламдўзлик анъаналарини халқаро бренд даражасига олиб чиқиш мухим ўрин тутади.

\section{Адабиётлар /Литература /References}

\section{1.https://president.uz/uz/lists/view/1255(https://president.uz/uz/lists/view/1255.}

2. Логофет Д.Н. Бухарское ханство под русскими протекторатом. т. 1,2 - СПб. 1911. - 245 с. - 208 c.(Logofet D.N. In the mountains and on the plains of Bukhara: (essays of Central Asia) / DN Logofet. - St. Petersburg: V. Berezovsky's edition, 1913. - VII,245 p; 2. Russia-Uzbekistan: from the history of relationships (collection) 208 p.) 
3. Н.В.Хаников Описание Бухарского ханства. - СПб. 1843 - С. 58.(N.V. Khanikov opisanie Bukharskogo khanstva(Description of the Bukhara Khanate). - SPb., 1843 - PP. 58.)

4. Юлдашева Г.К. Традиционная одежда и украшения женщин Нуратинской долины (конец XIX - начало XX века).: Автореф. дис. ... канд. истор. наук. - Т., 1995. - 21 с.( Yuldasheva G.K. Traditional clothes and jewelry of women of the Nurata Valley (late 19th - early 20th century) $\therefore$ Author's abstract. dis ... cand. History. Sciences. - T., 1995. - 21 p.)

5. Толипов Ф. Мозийга бўйлашган маскан (Гараша қишлоғи хақида тарихий-этнографик рисола. Т., 2008. // Tolipov F. The settlement adjacent to Mazi (Historical and ethnographic pamphlet about Garasha village. T., 2008.

6. Бердиев X. Нурота вохаси топонимларининг тарихий тахлили. // Тарих фанлари номзоди илмий даражасини олиш учун ёзилган дисс. Автореферати. Т. 2019. // Berdiev X. Historical analysis of toponyms of Nurata oasis. // Written dissertation for the degree of Candidate of Historical Sciences. Abstracts. T. 2019.

7. Пардаев Т.Хунармандчилик анъаналари// Moziydan sado 2. (58).2013 - Б. 29-30.(Pardaev Т. Traditions of handicrafts // Moziydan sado 2. (58). 2013 - PP. 29-30.)

9. Мошкова В.Г. Ковры народов Средней Азии конца XIX - начало XX вв. Материалы экпедиций 1929-1945 гг. -Ташкент, Фан, 1970. - С. 135-158, 238.( Moshkova V.G. Carpets of the peoples of Central Asia of the late 19th - early 20th centuries. Materials of expeditions 19291945 - Tashkent, Fan, 1970. - PP. 135-158, 238.)

10. Мошкова В.Г. Ковры народов Средней Азии конца XIX - начало XX вв. Материалы экпедиций 1929-1945 гг. -Ташкент, Фан, 1970. - С. 135-158, 238.( Moshkova V.G. Carpets of the peoples of Central Asia of the late 19th - early 20th centuries. Materials of expeditions 19291945 - Tashkent, Fan, 1970. - PP. 135-158, 238.)

11. Семёнов А. История Бухарских мангитов.// Бюллетен. САГУ. Вып. 4. - Ташкент, 1924. C. 46.( Semyonov A. History of Bukhara mangits. // Bulletin. SAGU. Issue 4. - Tashkent, 1924. PP. 46.) 